\title{
Modeling of a Prosumer in Optimal Design Energy Systems Problem
}

\author{
Evgeny Barakhtenko ${ }^{1}$, Dmitry Sokolov ${ }^{1}$ and Veronica Tashlykova ${ }^{1, *}$ \\ ${ }^{1}$ Melentiev Energy Systems Institute of Siberian Branch of the Russian Academy of Sciences (ESI SB \\ RAS), Pipeline Energy Systems Department, 130, Lermontov str., Irkutsk, Russia, 664033.
}

\begin{abstract}
The conversion of existing energy systems to intelligent integrated energy systems can happen only if economic benefits due to introduction of the intelligent integrated energy systems will exceed required level of investments. Thus, it is necessary for every optimal design energy systems problem according to the purposes of the study to determine various aspects of equipment configuration, investment and a proposed unit commitment on a case-by-case basis. The studies, taking under consideration energy efficiency of renewable energy units, are particularly important as environmental safety standards are increasing. In the paper optimal design of prosumer energy supply system problem in the intelligent integrated energy system was investigated. For this purpose a super structure for an energy supply system includes different generating capacities with relevant power range. The superstructure for prosumer energy supply system consists of an electric boiler, a gas-fired boiler, a solar photo-voltaic, a solar heating system and a gas-fired CHP. An ability of district energy system to receive the excess generating energy is restricted by the constraints. The heat and electricity tariffs and the received to district energy supply system energy constraints are varying according to time period. As a result of this study, cost-effectiveness analysis of chosen equipment configuration was undertaken.
\end{abstract}

\section{Introduction}

A consumer, who manages his energy consumption, is called a prosumer [1-5]. Depending on the availability of self-generating facilities, prosumer falls into one of following categories: the first type of prosumer [5] (generation equipment is absent, but this type prosumer still manages own energy consumption by shifting part of load to peak-off periods) and second type of prosumer (this type prosumer is able to deliver energy to the district energy supply system and control the load of his own generation units). In this paper the second type of prosumer is considered, i.e. a consumer, which has self-generating facilities. The research of prosumer energy supply systems is faced with the following problems [6-9]: finding of optimal mix of prosumer self-generating equipment [10-15] and its corresponding operational costs and finding of optimal design of prosumer energy supply system by determine the equipment configuration [16-18] and its corresponding

\footnotetext{
*Corresponding authorop: vsb@isem.irk.ru
} 
total costs. The important condition of both problems is meeting the thermal and electrical prosumer demand. This paper is devoted to the solution of the second one problem.

\section{Mathematical statement of the problem}

The design problem of prosumer energy supply system is to determine optimal equipment configuration of thermal and electrical energy generation units. Given the heating and electrical demands, the capacities of equipment, the prices for primary energy resources and the prices for energy purchased from district energy supply system, the goal is to design an energy supply system at minimum cost.

It is necessary to minimize the objective function of prosumer energy supply system total costs that has the form:

$$
f\left(h, e, h_{s, t}, e_{s, t}, D_{s m, t}^{e}, Q_{s t o r}\right)=\sum_{i=1}^{I} \alpha_{i}\left(a C_{\text {capex }, i}+C_{m a \text { in }, i}\right)+\sum_{t=1}^{T} C_{\text {fuel }, i, t}+C_{\text {star }, i}-R_{i, t}+C_{d s, t} \rightarrow \min
$$

where $h$ - thermal energy generated by prosumer; $e$ - electric energy generated by prosumer; $h_{s, t}$ - heat purchased from district heating system at time $t ; e_{s, t}$ - electricity purchased from power grid at time $t ; D_{s m, t}^{e}-$ shiftable demand at time $t$, this load can be shift on any time during that day; $Q_{\text {stor }}$ - heat storage capacity; $\alpha_{i}$ - binary variable representing the operational status of unit $i$ (0 - switch off, 1 - switch on); $a$ - capital recovery factor; $C_{\text {capex }, i}$ - investment of unit $i ; C_{\text {mant }, i}-$ maintenance cost of unit $i ; C_{\text {fuel }, i, t}-$ cost of primary energy resources to produce the required amount of thermal and electric energy by unit $i$ at time $t ; C_{\text {start }, i}$ - start-up cost of unit $i ; R_{i, t}$ - revenue from supplied heat generated by unit $i$ to the district energy supply system at time $t ; C_{d s, t}-$ costs of electric and thermal energy purchased from district energy supply system at time $t$.

The components of objective function were determined according to the following equations:

$$
\begin{aligned}
C_{f u e l, i, t} & =p_{\text {fuel }} b_{i, t} \eta_{i} Q_{t}^{p}, C_{\text {start }, i}=Z p_{\text {start }, i}, C_{d s, t}=e_{s, t} p_{e, D S}+h_{s, t} p_{h, D S}, \\
R_{i, t} & =\left(e_{t}-D_{t}^{e}\right) p_{e, D S}+\left(h_{t}-D_{t}^{h}\right) p_{h, D S}, D_{t}^{e}=D_{\text {const }, t}^{e}+D_{s m, t}^{e},
\end{aligned}
$$

where $p_{\text {fuel }}$ - fuel cost; $b_{i, t}$ - consumption of primary energy resource by unit $i$ at time $t$; $\eta_{i} \quad-$ efficiency of unit $i ; Q_{u}^{p}-$ the conversion factor of the primary energy resource to the required energy type; $Z$ - amount of starts of unit $i$ during time $t \in[0 ; T] ; p_{\text {start }, i}$ - price for start-up unit $i ; p_{e, D S}$ - price for electricity purchased from power grid; $p_{h, D S}-$ price for heat purchased from district heating system; $D_{t}^{e}-$ total electric demand of prosumer at time $t ; D_{t}^{h}$ - heat demand of prosumer at time $t ; D_{\text {const, } t}^{e}-$ unshiftable electric demand, this load should be covered exactly at time $t ; D_{s m, t}^{e}-$ shiftable electric demand at time $t$, this load can be shift on any time during that day.

Subject to:

$$
\begin{gathered}
e_{t}+e_{s, t} \geq D_{t}^{e}, h_{t}+h_{s, t}+h_{s t o r, t} \geq D_{t}^{h}, 0 \leq \sum_{t=1}^{T} D_{s m, t}^{e} \leq D^{\max } e_{\min } \leq e \leq e_{\max }, \\
h_{\min } \leq h \leq h_{\max }, \quad Z_{\min } \leq Z \leq Z_{\max }, 0 \leq e_{s, t} \leq e_{s, t}^{\max }, 0 \leq b_{t} \leq b_{t}^{\max },
\end{gathered}
$$




$$
0 \leq \sum_{t=1}^{T} b_{t} \leq B, 0 \leq Q_{i} \leq Q_{\max }, \quad 0 \leq h_{t}-D_{t}^{h}+h_{s t o r, t} \leq n_{h, t},
$$

where $h_{\text {stor, } t}$ - heat delivered from heat storage at time $t ; B$ - total amount of primary energy resource during time $T ; Q_{\max }-$ maximum capacity of heat storage; $n_{h, t}-$ maximum thermal energy supplied by prosumer to district heating system.

The above generalized problem statement was reduced to solving the problem of mixed integer linear programming by linearization of nonlinear inequalities [19].

\section{Case studies}

The superstructure of prosumer energy supply system is presented on figure 1 . The selfgenerating facilities of the prosumer includes a gas fired CHP, an electric boiler (EB), a heat pump (HP), a solar heating system (SHS) and a solar photovoltaic (SPV). Also the heat storage and electric demand formation are depicted on Figure 1.

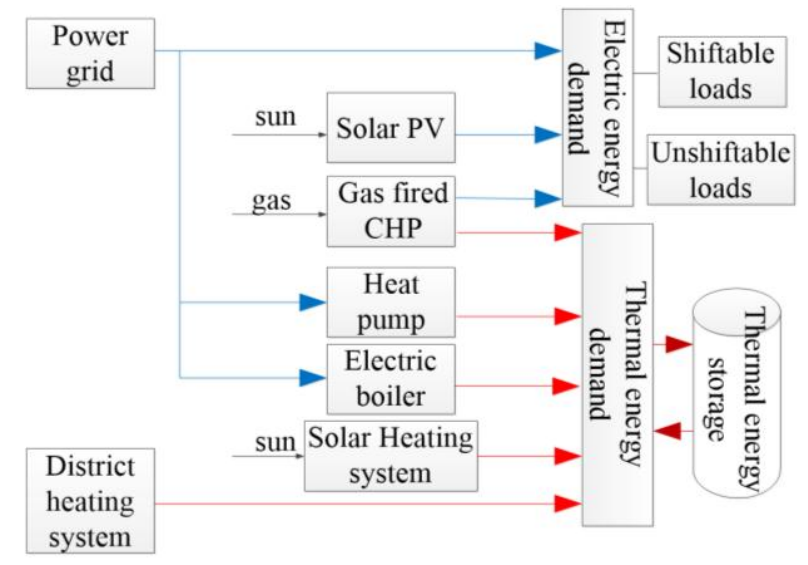

Fig. 1. The energy hub model of the residential district.

The nonlinear performance curves of CHP and HP are linearized by the method of least squares. The CHP electric capacity is $100 \mathrm{~kW}$ and CHP heating output is $178 \mathrm{~kW}$, required investment of this unit 9,5 million rub. The capital cost of $100 \mathrm{~kW}$ SPV is 5 million rub. The SHS with $176 \mathrm{~kW}$ heating output is cost 1,4 million rub. The HP with $180 \mathrm{~kW}$ capacity is cost 1,6 million rub. The capital cost of EB is 0,5 million rub. In this paper prosumer energy supply system is considered quarterly for year. The daily heat load curves for each season of year are presented on Figure 2 and the daily electricity load curve of the prosumer is depicted on Figure 3 [20].

The daily shiftable electric demand value during year was set $40 \mathrm{kWh}$. The energy transmission and storage losses were set to $5 \%$. Price for natural gas is $4,65 \mathrm{rub} . / \mathrm{m}^{3}$. Prices for thermal and electric energy at peak time is 2,16 and $2,34 \mathrm{rub} . / \mathrm{kWh}$, in the daytime $-1,8$ and $1,08 \mathrm{rub} . / \mathrm{kWh}$ and at night $-1,2$ and $0,81 \mathrm{rub} . / \mathrm{kWh}$ respectively. 


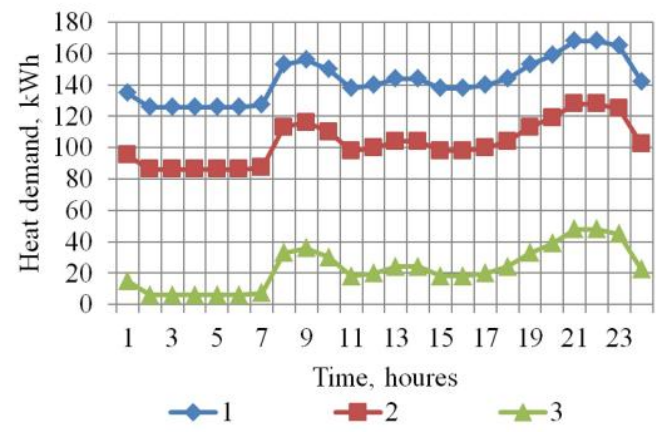

Fig. 2. The daily heat load curves.

1 - 1st quarter; 2 -2nd quarter; 3 - 3rd quarter;

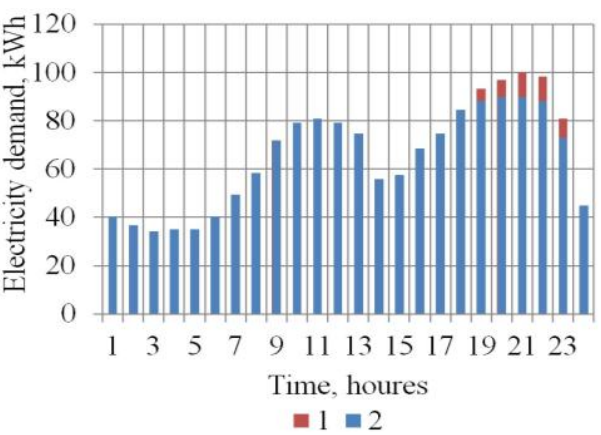

Fig. 3. The daily electricity load curve. 1 - shiftable demand; 2 - unshiftable demand.

\section{Results and discussion}

The received results assume use of district heating system as the main source of thermal energy and as additional one - SHS. The only source of electric energy is power grid.

The shiftable part of prosumer electric demand has been relocated to the lowest price zone (from midnight to 6 o'clock). The received electric demand distribution is similar for the whole year.

Heat demand is covered by district heating system supplies at night. In the morning hours, amount of thermal energy purchased from district heating system is reducted, as soon as there is SHS generation. Then, when SHS generation exceeds heat demand, the surplus is supplied to district heating system, as shown on Figure 4. Since 11 o'clock generated by SHS heat is enough for meeting prosumer demand, and for supplying thermal energy to district heating system and for accumulating of thermal energy in the heat storage. By 14 hours heat storage tank is full and delivery to district heating system reached the maximum allowed value, so possible value of generated on SHS thermal energy at this period cannot be stored or used and part of solar collectors is switched off. The thermal energy, accumulated between 11 and 12 hours, allows to reduce significantly amount of heat purchased from district heating system at peak zone. The second quarter of the year under review is illustrated on Figure 4 and Figure 5.

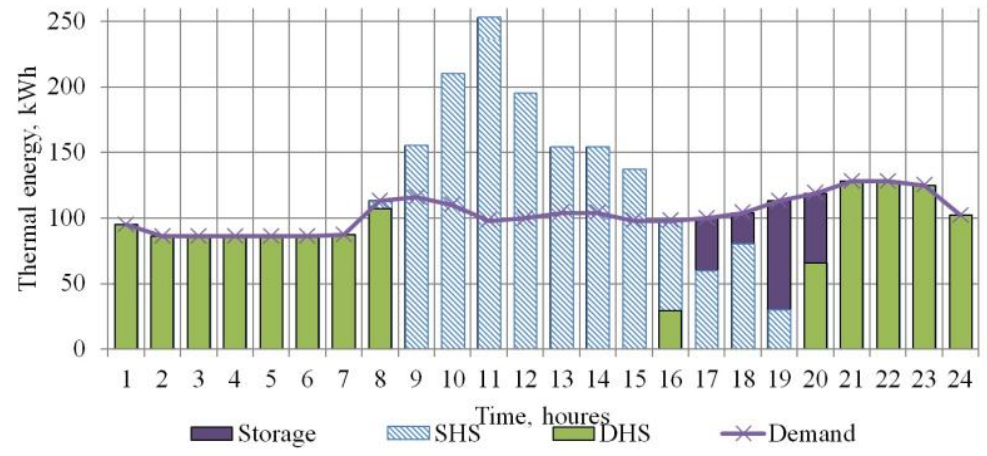

Fig. 4. Optimal schedule of heat supply in the second quarter. 


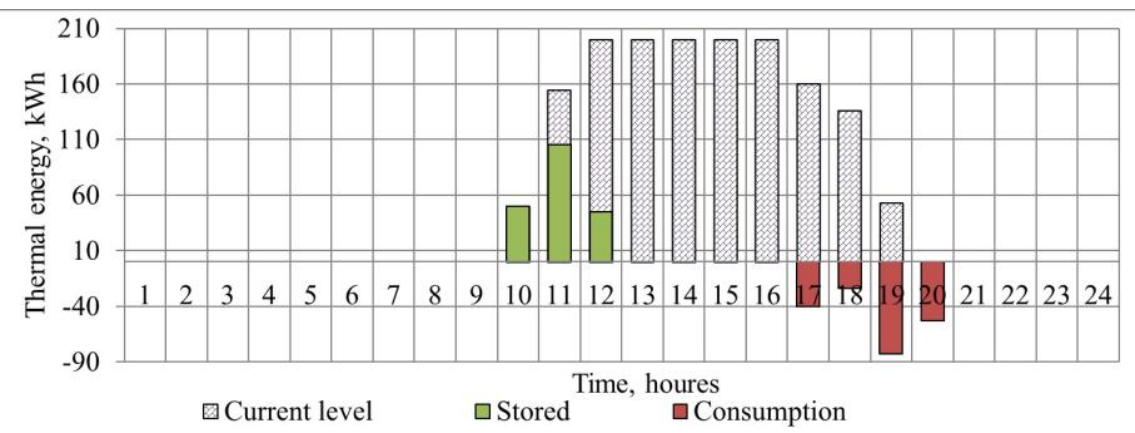

Fig. 5. Current level of thermal energy in heat storage in the second quarter.

Table 1. Comparison of the energy supply costs of a passive consumer and prosumer.

\begin{tabular}{|c|c|c|c|c|c|c|}
\hline $\begin{array}{l}\text { Consumer } \\
\text { type }\end{array}$ & $\begin{array}{l}\text { Cost of } \\
\text { electricity } \\
\text { purchased } \\
\text { from } \\
\text { power } \\
\text { grid, } 10^{3} \\
\text { rub./year }\end{array}$ & $\begin{array}{c}\text { Cost of } \\
\text { heat } \\
\text { purchased } \\
\text { from } \\
\text { district } \\
\text { heating } \\
\text { system, } \\
10^{3} \\
\text { rub./year }\end{array}$ & $\begin{array}{l}\text { Return on } \\
\text { investment, } \\
10^{3} \text { rub./year }\end{array}$ & $\begin{array}{l}\text { Revenue } \\
\text { from } \\
\text { deliveries } \\
\text { to district } \\
\text { heating } \\
\text { system, } 10^{3} \\
\text { rub./year }\end{array}$ & $\begin{array}{c}\text { Total cost } \\
10^{3} \\
\text { rub./year }\end{array}$ & $\begin{array}{c}\text { Economy, } \\
10^{3} \\
\text { rub./year }\end{array}$ \\
\hline Passive & 458 & 1437,6 & - & - & 1895,6 & - \\
\hline Prosumer & 449,1 & 1014,4 & 196 & 96 & 1463,5 & 432,1 \\
\hline
\end{tabular}

The prosumer power supply strategy assumes the onle source of elecricity is power grid. The prosumer heat supply syrategy assumes using of SHS and district heating system. The table 2 shows the total costs of passive consumer and prosumer under equal conditions: differentiated tariff for energy supply and the same volumes of heat demand and electric demand. The total costs of prosumer is decreased by $16 \%$, despite the fact that its costs include the return on investment from SHS. Due to the daily distribution of shiftable part of electric demand, the elecricity costs of prosumer are reduced by $2 \%$ compared to passive consumer. By installing the SHS unit, heating costs are reduced by $22,9 \%$ and it became possible to supply thermal energy to the district heating system. Thus, the payback period of the SHS unit under the same initial conditios will be 6 years.

\section{Conclusion}

Studies focusing on the benefits of transforming existing power systems into intelligent integrated power systems are particularly relevant. This work solved the problem of optimal design of the prosumer energy supply system taking into account the possibilities of heat and electricity demand distribution. As a result of the optimization task the following configuration of energy equipment was chosen: solar heating system and district heating system for heat supply, and electricity supply from the power grid.

The work was carried out within framework of scientific projects III.17.4.1 of the research program of the SB RAS AAAA-A17-117030310432-9. 


\section{References}

1. I. O. Volkova, M. V. Gubko, E. A. Sal'nikova, Problemy upravleniya, 6, 53 (2013)

2. YU. N. Kucherov, A. V. Ivanov, D. A. Korev, N. A. Utkin, A. Z. Zh ${ }^{\text {uk, }}$ Energeticheskaya Politika, 5, 73 (2018)

3. N. I. Voropai, Proc. of the International Conference on Management of Large-Scale System Development, 1, 34 (2018)

4. V. K. Aver'yanov, YU. V. Yuferev, A. A. Melezhik, A. S. Gorshkov, Academia. Stroitel'stvo i kul'tura, 1, 78-87 (2018)

5. V. A. Stennikov, E. A. Barahtenko, D. V. Sokolov, V. B. Shelekhova, Izvestiya vysshih uchebnyh zavedenij. Problemy energetiki, 19, 88 (2017)

6. N. I. Voropai, V. A. Stennikov, E. A. Barakhtenko, Journal of Physics: Conference Series, 1111, 012 (2018)

7. N. I. Voropai, V. A. Stennikov, Izvestiya Rossijskoj Akademii nauk. Energetika, 64 (2014)

8. N. Voropai, V. Stennikov, S. Senderov, E. Barakhtenko, O. Voitov, A. Ustinov. Journal of energy engineering, 147 (2017)

9. Voropai N., Stennikov V., Barakhtenko E. Studies on Russian Economic Development, 28, 492 (2017)

10. T. Liu, D. Zhang, S. Wang, T. Wu, Energy Conversion and Management, 182, 126 (2019)

11. D. Patteeuw, K. Bruninx, A. Arteconi, E. Delarue, W. D'haeseleer, L. Helsen, Applied Energy, 151, 306 (2015)

12. R. Rezaeipour, A. Zahedi, Solar energy, 157, 227 (2017)

13. G. Li, R. Zhang, T. Jiang, H. Chen, L. Bai, H. Cui, X. Li, Applied Energy, 192, 408 (2017)

14. G. Angenendt, S. Zurmühlen, F. Rücker, H. Axelsen, D. Sauer, Energy Conversion and Management, 1, 100005 (2019)

15. E. Barbour, M. Gonzáles, Applied energy, 215, 356 (2018)

11. A. Roth, M. Boix, V. Gerbaud, L. Montastruc, P. Etur, Journal of Cleaner Production, 223, 214 (2019)

11. S. Samsatli, N. Samsatli, Journal of Cleaner Production, 191, 458 (2018)

11. S. Samsatli, N. J. Samsatli, Applied Energy, 220, 893 (2018)

11. J. Marquant, R. Evins, J. Carmeliet, Procedia Computer Science, 51, 2137 (2015)

20. Information and technological support of integrated small-scale energy systems in the field of electricity and heat supply, Scientific and Technical Report (2012) 